\title{
International Business Education At Best B-Schools
}

Susan Eisner, (Email: seisner@ramapo.edu), Ramapo College of New Jersey

Mary Ellen O’Grady Harvey, (Email: mogrady@ramapo.edu), Ramapo College of New Jersey

\begin{abstract}
This paper investigates the preparation undergraduate students readying for participation in the global economy and interested in international business careers can receive at U.S. business schools. Existing literature point to the importance of internationalizing business education, but have been relatively silent in recent years regarding its status. Accordingly, this study seeks to contribute to business education and management practice by examining the attributes of international business programs currently offered by "best" business schools. Gap analysis and benchmarking tools are identified and summarized within the context of existing literature. Analysis and recommendation are provided to assist educators developing programs that successfully train graduates for the challenges and opportunities of today's international workplace.
\end{abstract}

\section{INTRODUCTION}

nternationalism has become central to many undergraduate business schools' missions. Benchmarking best practices in international business education is integral to the continual process of curriculum review that optimizes student learning and advances such programs' mission. This paper presents the results of an original in-depth study that explored components of the "best" current International Business programs offered by United States (U.S.) universities. A review of academic and practitioner literature revealed the increasing importance of preparing business students for the international workplace.

The trends are optimistic for students of international business. As the global economy continues to expand, demand for labor appears to be growing internationally. The rate of job growth outside the U.S. is at its peak since 2000. Some 18 countries showed job increases of $1.8 \%$ from 2005 to 2006, comparing favorably to an annual employment increase of $1.4 \%$ for the U.S. reported in December 2006. Favorable job trends are occurring in countries as geographically diverse as Canada, Argentina, Australia, and Great Britain. Brazil alone predicts a 2.7\% increase in jobs this year (Where the Jobs Are, 2007).

There are indications that local populations may not have the qualifications to fill these new jobs. A recent study by the McKinsey Institute estimates that only 160,000 of China's 1.6 million young engineers are qualified for multinational employment. That study similarly projects that only $10-25 \%$ of India's 14 million professionals are likely to be hired by multinational companies. Inadequacies in the educational systems of both countries are associated with this disconnect between large population size and insufficient number of qualified workers (Farrell, 2006). India is experiencing such shortages of qualified workers (Sengupta, Skills Gap, 2006) that some of its companies are recruiting at job fairs on U. S. campuses (Sengupta, In a Twist, 2006). The impact education can make is striking.

At the same time, studies report that recent U.S. college graduates are facing the best employment market since the dot-com bust. Undergraduate hiring for the class of 2006 estimated an annual increase of almost $15 \%$ (Gangemi, 2006), and those who have majored in business are in highest demand (Collegiate Employment Research Institute, 2007). A 2006 survey by Universum Communication of 17,000 undergraduate U.S. business students identified the companies for whom the students would most like to work. The top ten employers they cited were, in 
order of student preference ranked first to tenth: The Walt Disney Company, Pricewaterhouse Cooper, Ernst \& Young, Google, Deloitte \% Touche, Nike, Merrill Lynch, Goldman Sachs, Apple, and the FBI (They Love It Here, 2006). The first nine of these, and all except the FBI, are global companies. There seems to be a convergence between opportunity for international employment and openness of U.S. business students toward such employment.

\section{IMPERATIVE}

Some are calling the consequences of that convergence an imperative for U. S. institutions of higher education to serve. The Ford and Carnegie Foundations began to express the need to internationalize business studies for U. S. students in the 1960s (Fugatte \& Jefferson, 2001). The U. S. Congress also foresaw as early as 1965 that it was in the long-term economic interest of the country to increase international business skills. In 1988, the U.S. government began actively supporting and funding linkages between educational institutions and businesses by establishing its Centers for International Business Education Program. Through that program, grant applications from universities proposing to host Centers for International Business Education and Research (CIBER) are reviewed for financial award. The CIBERs are to serve as national resources for teaching, outreach, and research in relevant aspects of international business and management including language, culture, commerce, markets, and security. The magnitude of this program is seen most recently in the 2002-2006 Department of Education funding cycle; it supported some 900 initiatives at CIBERs housed at 30 universities across the country (Fifteen Years in the Making of CIBEs, 2007; Best Practices, 2007).

Today's business and interested non-profit organizations appear to be on the same page. The Business Roundtable and National Academy of Sciences are among the many reporting the need to increase international knowledge, language ability, and intercultural communication skills of U. S. graduates. They say that students educated outside the U.S. receive those skill sets as a part of higher education, and U. S. employers cannot afford to teach such expertise on the job (Kaufman \& Johnson, 2006). Society of Human Resource Management (SHRM) President and CEO Susan Meisinger echoes the concern stating, "New entrants to the U.S. workforce are not demonstrating levels of excellence necessary to compete successfully in the face of rising global labor market challenges (The Conference Board, 2006)." A joint study of human resource professionals conducted recently by SHRM, The Conference Board, Partnership for $21^{\text {st }}$ Century Skills, and Corporate Voices for Working Families specifically projects the increasing need for U.S. workforce entrants to know foreign languages, cultures, and global markets (The Conference Board, 2006). Considering U.S. expatriate failure rates estimated at 40-55\%, cost per failure estimated at $\$ 250,000$ - $\$ 1,000,000$, and more than $40 \%$ of successful expatriates leaving the company within two years of retuning home (Johnson, J., Lenartowicz, T. \& Apud, S., 2006), the imperative for U.S. institutions of higher learning to help increase international business competencies is apparent.

Academic institutions seem to be equally cognizant of the priority. The National Business Education Association (NBEA) views international business as "an area of the business education that commands center stage in today's global economy" (NBEA, 2007). Moreover, eligibility procedures for AACSB accreditation specify that to fulfill its standards business schools must demonstrate that they ready graduates for global participation. According to AACSB, "Every graduate should be prepared to pursue a business or management career in a global context (AACSB, 2006)." Reflecting the changing role of business schools in international business education, AACSB has changed its name from the American Assembly of Collegiate Schools of Business to AACSB - The International Association for Management Education (Walton \& Basciano, 2006).

Opportunity and openness toward international business appear to be matched by a legitimacy that business educators can factor in as they weigh competing priorities. International business education is not a fad; it is part of the fabric of contemporary business education. This paper investigates a timely topic, then: the grounding undergraduate students readying for the global economy and interested in international business careers can receive at U.S. business schools. The study presented explored international business education practices of "best" business schools as a gap analysis tool for undergraduate curriculum development at a public four-year college. Results may assist others seeking to prepare students for the challenges and opportunities of the international workplace. 


\section{PURPOSE AND METHOD}

Research for this study began with a review of the secondary literature to provide foundational information, criteria with which to construct the list of target schools to be investigated through primary research, and context within which to analyze results of that primary research. Academic databases including ABIINFORM Global, ProQuest, and Google Scholar were searched using key word combinations of international business education, global careers, competencies, skills, expatriates, recruitment, hiring, multinational, management training, management education, college graduates, job trends, best practices, curriculum, and standards. Practitioner and general public websites including Business Week online and New York Times online were searched using similar locators. Individual websites identified by the searches to have specialized knowledge including The Conference Board, Department of Education, Michigan State University, and NBEA were then visited. From this, some 75 articles were retrieved and considered.

Methodology used to conduct the primary research for this study involved establishing criteria to select the colleges and universities (schools) to be examined, deciding the nature of the data to be collected, and developing procedures for data collection and analysis. This involved several steps. First, five sources published in the same recent year (2006) were used to develop a list of international business (IB) education programs to be investigated: rankings of undergraduate business programs published in Business Week (Lavelle, L., Gerdes, L., Jespersen, F. \& Gloeckler, G., 2006) and in U.S. News (Best Business Programs, 2006), rankings of top undergraduate IB major programs published in U.S. News (Best Business Programs, 2006), and rankings of top business graduate programs published in Business Week (Lavelle \& Lehman, 2006) and in U.S. News (America's Best Graduate Schools, 2006).

The information from the above five lists provided the population from which the "best b-school" sample was chosen. The top 15 ranked schools on each of the Business Week and U.S. News lists were reviewed. The starting point was the Business Week undergraduate list because it was developed based on more comprehensive measures (several indicators of excellence ${ }^{1}$ and five sources of data ${ }^{2}$ were combined to form the ranking) than U.S. News which ranked schools based on peer review (self-reported data from Deans and senior faculty).

If a school ranked within the top 15 on the Business Week undergraduate list and also appeared within the top 15 of either of the U.S. News undergraduate lists reviewed, it was included in the sample. In addition, any school ranked in the top 10 undergraduate IB programs by U.S. News not already on the target list was added to the sample. Lastly, the remaining four institutions whose MBA programs ranked with the top eight graduate business programs but whose business programs were not already included in the sample from the undergraduate Business Week and U.S. News lists were added to the sample. The purpose of this was to evaluate the possibility of relevant IB undergraduate programs at institutions that did not make the top-ranked undergraduate business program lists.

The above analysis resulted in a target list of 21 schools for initial review. Seventeen of these were based on the undergraduate criteria, and four were based on the graduate criteria. A review of websites for schools based on the graduate criteria determined that none of the four had relevant undergraduate IB programs. The sample of best $b$-schools to be used in this study was then finalized as including 17 business schools. Table 1 contains those resulting schools mapped to the criteria applied.

Having generated the sample, the AACSB website was then accessed to determine the accreditation status of the sample schools. Every school in the target list is accredited by AACSB, none were accredited in the current year, and none recently received maintenance accreditation. Attributes for data collection were identified from relevant secondary literature, and are detailed in Appendix 1. Factors explored included whether the undergraduate business school requires an IB course, offers a specialized IB major/concentration and/or minor, provides interdisciplinary IB education linking business and non-business schools, internationalizes experiential learning, houses IB research institutes/centers, and hosts IB student organizations. All business programs investigated are offered traditionally; distance learning is not the focus of this study. 
Table 1: Best B-school Sample Mapped to Criteria

\begin{tabular}{|c|c|c|c|c|c|}
\hline & $\begin{array}{c}\text { BW } \\
\text { Undergrad } \\
\text { Business } \\
\end{array}$ & $\begin{array}{c}\text { US News } \\
\text { Undergrad } \\
\text { Business }\end{array}$ & $\begin{array}{c}\text { US News } \\
\text { Undergrad } \\
\text { IB } \\
\end{array}$ & $\begin{array}{l}\text { US News } \\
\text { Graduate } \\
\text { Business } \\
\end{array}$ & $\begin{array}{c}\text { BW } \\
\text { Graduate } \\
\text { Business } \\
\end{array}$ \\
\hline U. Pennsylvania (Wharton) & 1 & 1 & 4 & 3 & 2 \\
\hline U. Virginia (McIntire) & 2 & $9-10$ & $22-25$ & $13-14$ & 15 \\
\hline MIT (Sloan) & 4 & 2 & & $4-5$ & 7 \\
\hline Emory (Goizueta) & 5 & $13-17$ & & $18-19$ & 23 \\
\hline U. Michigan - Ann Arbor (Ross) & 6 & $3-4$ & 3 & $11-12$ & 5 \\
\hline NYU (Stern) & 7 & $5-7$ & 2 & $13-14$ & 14 \\
\hline U. Texas - Austin (McCombs) & 9 & $5-7$ & 6 & $18-19$ & 20 \\
\hline $\begin{array}{l}\text { U. N. Carolina - Chapel Hill } \\
\text { (Kenan-Flagler) }\end{array}$ & 11 & $5-7$ & $15-17$ & 20 & 17 \\
\hline U. California - Berkeley (Haas) & 12 & $3-4$ & 5 & $7-8$ & 8 \\
\hline Georgetown (McDonough) & 13 & $23-28$ & $8-9$ & $34-37$ & 22 \\
\hline Cornell & 14 & $11-12$ & & $16-17$ & 13 \\
\hline Washington - St. Louis (Olin) & 15 & $13-17$ & & $26-27$ & 27 \\
\hline U. S. Carolina - Columbia (Marshall) & & $42-50$ & 1 & & \\
\hline Florida International & & $150-183$ & 7 & & \\
\hline U. Missouri - St. Louis & & $150-183$ & $8-9$ & & \\
\hline Temple (Fox) & & $73-82$ & $10-11$ & & \\
\hline San Diego State & & $83-98$ & $10-11$ & & \\
\hline Harvard & & & & 1 & 4 \\
\hline Stanford & & & & 2 & 6 \\
\hline Northwestern & & & & $4-5$ & 3 \\
\hline U. Chicago & & & & 6 & 1 \\
\hline
\end{tabular}

The AACSB website and websites of each of the 17 remaining targeted schools were visited for data collection. Websites of targeted schools were reviewed at both the business school and university level ${ }^{3}$. If the data was not available on either the AACSB or target school website, the business school and/or university registrar were telephoned and emailed to attempt to collect the data.

Review of the secondary literature was both formative in constructing the relevant attributes for primary research ${ }^{4}$, and in revealing its importance. Academic and practitioner literature are consistent in pointing to the urgency of internationalizing business education, but have been relatively silent in recent years regarding its status. Accordingly, this paper seeks to contribute to the literature, business education, and through them to management practice by examining the core factors identified above, and identifying the strategic implications that the findings present.

\section{RESULTS}

The business schools this study reviewed as "best" span basic institutional and structural characteristics. They vary in public vs. private status, degree type awarded, student enrollment, and student-faculty ratio. As detailed in Table 2, the schools are more likely to be public than private, about as likely to have business school enrollments under 1000 students as above 1000 , more likely to have student-faculty ratios of less that 25:1, and about as likely to have student-faculty ratios under 16 as over 25 . Of the six schools offering Bachelor of Science (BS) degrees two offer the BS, one offers its BS in Economics, one offers its BS in Commerce, one offers its BS in Management Science, and one offers its BS in Management.

The research found just about one-half of the sampled schools having CIBERs. Given the institutional and resource commitment to internationalizing this suggests, the eight CIBER schools were examined as a subset of the sample. Those eight schools are Florida International, San Diego State, Temple, University of Michigan - Ann Arbor, University of North Carolina - Chapel Hill, University of Pennsylvania, University of South Carolina - 
Columbia, and University of Texas - Austin. As compared with all 17 schools sampled for this study, the eight CIBER schools were more likely to offer the BBA (Bachelor in Business Administration) degree, be public, be large, have more part-time students, and have larger classes.

Table 2: Institutional/Structural Characteristics

\begin{tabular}{|c|c|c|c|c|}
\hline Attribute & \multicolumn{2}{|c|}{ All Schools (17) } & \multicolumn{2}{|c|}{ Ciber Schools (8) } \\
\hline Degree & \# Schools & $\%$ of Sample & \# Schools & $\%$ of CIBER Sample \\
\hline BS & 6 & $35 \%$ & 1 & $12.5 \%$ \\
\hline BBA & 5 & $29 \%$ & 4 & $50 \%$ \\
\hline BSBA & 5 & $29 \%$ & 2 & $25 \%$ \\
\hline BA & 1 & $6 \%$ & 1 & $12.5 \%$ \\
\hline Public & 10 & $59 \%$ & 7 & $88 \%$ \\
\hline Private & 7 & $41 \%$ & 1 & $12 \%$ \\
\hline \multicolumn{5}{|c|}{ Business School Enrollment } \\
\hline$<600$ & 3 & $18 \%$ & 0 & $0 \%$ \\
\hline $601-1000$ & 5 & $29 \%$ & 2 & $25 \%$ \\
\hline $1001-3000$ & 5 & $29 \%$ & 2 & $25 \%$ \\
\hline$>3000$ & 4 & $24 \%$ & 4 & $50 \%$ \\
\hline Full Time Only & 10 & $59 \%$ & 2 & $25 \%$ \\
\hline \multicolumn{5}{|l|}{ Students Per Faculty } \\
\hline$<15$ & 4 & $24 \%$ & 2 & $25 \%$ \\
\hline $16-25$ & 8 & $47 \%$ & 2 & $25 \%$ \\
\hline$>25$ & 5 & $29 \%$ & 4 & $50 \%$ \\
\hline
\end{tabular}

Reviewing features of the IB programs at the 17 schools found a substantial majority (82\%) to be providing an IB major or concentration (major), ${ }^{5}$ but comparably few (35\%) to be requiring an IB course in the business core. Every school requiring an IB core course ${ }^{6}$ offered IB as a major; none of the three schools ${ }^{7}$ not offering an IB major require an IB course in the core business curriculum. Four $^{8}$ of the 14 schools (29\%) that offer an IB major require their IB students to also major in a functional area of business (e.g., Accounting, Finance, Management, Marketing).

Campus IB engagement outside of class appears common at best IB programs. Most (65\%) schools have CIBER and/or other IB research centers; ${ }^{9}$ almost all have IB or other international student organizations.

The CIBER schools sampled were more pronounced in each program feature this study reviewed. Seven ${ }^{10}$ of the eight schools offer an IB major, only one ${ }^{11}$ of the eight requires an IB course in the business core, and each of the eight has IB student organizations and IB research centers. Table 3 details findings.

Table 3: IB Program Features

\begin{tabular}{|c|c|c|c|c|}
\hline Attribute & \multicolumn{2}{|c|}{ All Schools (17) } & \multicolumn{2}{c|}{ Ciber Schools (8) } \\
\hline & \# Schools & \% of Sample & \# Schools & \% of CIBER Sample \\
\hline IB major/concentration available & 14 & $82 \%$ & 7 & $88 \%$ \\
\hline IB course required in business core & 6 & $35 \%$ & 1 & $13 \%$ \\
\hline IB/international student organizations & 17 & $100 \%$ & 8 & $100 \%$ \\
\hline CIBER & 8 & $47 \%$ & 8 & $100 \%$ \\
\hline Other IB research centers & 9 & $53 \%$ & 6 & $75 \%$ \\
\hline
\end{tabular}


Reviewing features of the IB majors at the 14 of 17 sampled schools that offer IB majors found results summarized in Table 4 and delineated in Appendix 3. The number of IB courses beyond the business core required of IB majors at these schools range from two to seven, with more than half of these schools requiring four IB courses. The required IB courses tend to be supplemented by other requirements, with language being required in more than three-quarters of the majors (79\%) and between-school differences in what satisfies the language requirement. Schools with language requirements vary in the number, level, and nature of language to be taken, and some allow testing out to satisfy the requirement.

Regional studies and study abroad were the next most frequent requirement supplementing the IB core for IB majors, with about half of the schools requiring each (57\% require regional studies; $50 \%$ require study abroad). $\mathrm{Two}^{12}$ of the eight schools requiring regional studies require IB majors to focus in one geographic area. Tendency to require study abroad was not matched by a tendency to require internships of IB majors; only three ${ }^{13}$ of the 14 schools include an internship in their IB major and that internship is not necessarily overseas in nature. On the other hand, five of the 14 schools have IB majors with language, regional studies, and study abroad requirements. Those five schools ${ }^{14}$ all ranked within the U.S. News top 10 undergraduate IB programs, and all except one of the five ${ }^{15}$ are CIBER schools.

Reflecting the tendency to supplement the IB core with additional requirements like those itemized above, the great majority (86\%) of IB majors at the 14 schools are interdisciplinary. This is primarily due to regional and language study requirements, which are frequently offered elsewhere in the university. Only two of the schools in the sample, though, offer an interdisciplinary IB degree. One of these, San Diego State University, offers a BA degree jointly by its business and liberal arts schools. The other, University of Pennsylvania, offers both a disciplinary business degree for IB majors and an interdisciplinary degree for IB honor students in conjunction with the liberal arts school.

Less than a third ${ }^{16}$ of the 14 schools (29\%) from the sample that offer IB majors require a functional major in addition to the IB major. A little more than a third of the 14 schools (36\%) that offer IB majors include an IB quantitative course requirement in the major, and each of these mandate one such course. Four ${ }^{17}$ of those five schools have International Finance as the required quantitative course; the fifth ${ }^{18}$ allows student choice among its quantitative IB courses, which include International Finance. When overall course offerings including electives are reviewed, most of the 14 schools include a quantitative course among their electives.

How do the IB major curriculum and program requirements in schools with CIBER centers compare? The CIBER schools sampled are more likely to require language, regional studies, quantitative courses, internship, and study abroad with the latter (internship and study abroad) showing the most pronounced comparative increase.

Table 4: IB Major/Concentration Features

\begin{tabular}{|l|c|c|c|c|}
\hline \multicolumn{1}{|c|}{ Attribute } & \multicolumn{2}{c|}{ All Schools (14) } & \multicolumn{2}{c|}{ Ciber Schools (8) } \\
\hline & $\#$ & $\%$ of Sample & \# & $100 \%$ \\
\hline \# schools with IB major/concentration & 14 & $100 \%$ & 7 & $14 \%$ \\
\hline \# IB courses required & & & & 1 \\
\hline Two & 1 & $7 \%$ & 1 & $14 \%$ \\
\hline Three & 3 & $22 \%$ & 3 & $44 \%$ \\
\hline Four & 8 & $57 \%$ & 1 & $14 \%$ \\
\hline Five & 1 & $7 \%$ & 1 & $14 \%$ \\
\hline Seven & 1 & $7 \%$ & 3 & $43 \%$ \\
\hline Quantitative IB course required & 5 & $36 \%$ & 6 & $86 \%$ \\
\hline Foreign language required & 11 & $79 \%$ & 4 & $57 \%$ \\
\hline Regional studies required & 8 & $57 \%$ & 3 & $43 \%$ \\
\hline Internship required & 3 & $21 \%$ & 5 & $71 \%$ \\
\hline Study abroad required & 7 & $50 \%$ & 6 & $86 \%$ \\
\hline IB program interdisciplinary & 12 & $86 \%$ & 2 & $29 \%$ \\
\hline Functional major also required & 4 & $29 \%$ & & \\
\hline
\end{tabular}


Within the common framework required by many of the IB major programs reviewed, there also appears to be room for innovation and individuality. The University of North Carolina, for example, offers a Global Learning Opportunities in Business Education (GLOBE) program in which students spend two semesters at partner schools in Asia and Europe. San Diego State University offers a multiple IB degree program in which students split their studies with a Mexican University (ITESM) and receive degrees from both institutions. San Diego State is also the only institution sampled to offer an IB program/degree separated from its other seven business majors. Florida International University appears to offer the most prescribed IB major, requiring the maximum number of courses mandated by any sampled school and specifying what those required courses are ${ }^{19}$. At the other end of the spectrum, the University of Michigan offers no IB major or required IB core course but allows students to internationalize their business studies through electives. In addition, it hosts a wide variety of IB student organizations, conferences, and research centers in addition to its CIBER through which students can arrange to Study Abroad. Of the other two schools in the sample that do not offer an IB major, Massachusetts Institute of Technology and Cornell University, the publicly available data searched showed comparatively little IB programmatic activity at the undergraduate level.

Application, experiential learning, and language proficiency are among the aspects of IB education recommended by existing literature. Here, too, there appear to be several approaches. Temple University's IB majors complete a capstone course in which they function as consultants for clients from the University's Small Business Development Center. University of Missouri's IB majors must learn a language used in international commerce. University of Pennsylvania's IB majors take one upper level language after meeting a basic foreign language competency requirement (instruction is offered in over 100 languages); the students in University of Pennsylvania's IB honors program take four upper level courses, choosing from 11 target languages. New York University requires study abroad of all its business students, and fully subsidizes those experiences.

Selectivity appears to be a feature of some IB programs. The University of South Carolina limits its IB major to 50 new admits annually. Four of the 17 schools sampled offer honors programs for their IB students. Requirements of those honors programs vary, as seen in Table 5.

\section{Table 5: IB Honors Program Features}

\begin{tabular}{|l|l|}
\hline \multicolumn{1}{|c|}{ School } & \multicolumn{1}{c|}{ Attributes } \\
\hline Florida International & $\begin{array}{l}\text { Different degree earned: BBA in International Business Honors, enter in junior year, must also be } \\
\text { in college-wide honors program, two honors tracks (region/language or business functional area), } \\
\text { and IB community service project }\end{array}$ \\
\hline San Diego State & $\begin{array}{l}3.25 \text { GPA at graduation, 3 } \\
\text { internship must be done abroad, honors thesis, and senior honors thesis }\end{array}$ \\
\hline U. of Missouri & Prescribed IB courses, foreign internship \\
\hline U. of Pennsylvania & $\begin{array}{l}\text { Joint degree earned: BS Economics and BA International Studies, 45 enter as freshmen annually, } \\
\text { additional language and international studies courses, senior thesis, and study abroad in location } \\
\text { of language studied }\end{array}$ \\
\hline
\end{tabular}

\section{ALIGNMENT}

Existing literature tends to identify four routes that business schools have taken over the years to internationalize their curricula. The first of these is integration, in which international content is infused throughout courses in the business core. The second is focus, in which the business and/or major core includes a designated IB course. The third is specialization, in which an IB major, concentration, or minor is offered. The fourth is hands-on, in which internships, study abroad, and foreign exchange opportunities are provided for students and faculty (Walton \& Basciano, 2006; Shetty \& Rudell, 2002). The best b-school sample profiled in this study appears to align with that literature both in variety of paths taken and in usage of focus, specialization, and hands-on routes. Data was not collectable regarding the first route, integration, but the increased inclusion of global content and cases in business school textbooks (Shetty \& Rudell, 2002) makes it a likely component at this study's sample schools, too. 
Are these routes sufficient? Some are concerned. The integration approach is vulnerable to infused content being skipped in functional area classes seeking to further disciplinary learning outcomes (Walton \& Basciano, 2006). The focus approach is vulnerable due to limited availability in programs already overcrowded with requirements (Ahlawat, 2006). The specialization approach is vulnerable to resource constraints, as reflected in a 1996 study finding the majority of AACSB Deans opposing an IB major (Walton \& Basciano, 2006). It may also be vulnerable to self-selection, since international students tend to enroll in IB majors (Shetty \& Rudell, 2002). The hands-on approach is also vulnerable to self-selection, but also to expense too costly for students and possible overemphasis on a limited number of industrialized nations where the goal of gaining "worldmindedness" may give way to tourism and adventure instead (Fugate \& Jefferson, 2001). Moreover, relatively few students take advantage of travel and study abroad programs (Walton \& Basciano, 2006). To the extent that the tendency of those more geocentric to be more likely to participate is a limiting factor, the fact that only $1 \%$ of the 19 million students enrolled in U.S. higher education own a passport (Kaufman \& Johnson, 2006) is a reality to consider.

Alternatively, there are indications that regardless of method, U.S. business schools are internationalizing their programs with positive outcomes. Reducing ethnocentricity tends to increase capability of working with those from other countries, and contemporary business education appears to be contributing to that. Studies find today's business students less ethnocentric than their non-business school peers. Moreover, students who have taken an IB course are found to be significantly less ethnocentric than those who have not. Additionally, travel and study abroad programs seem to help U.S. students become less ethnocentric, and students who speak more than one language are found to be less ethnocentric than those who do not (Walton \& Basciano, 2006).

To what extent does size predict that a business program will be internationalized? A 2001 AACSB survey showed larger schools more likely than smaller schools to offer their undergraduate students an IB major or minor (Shetty \& Rudell, 2002). The best b-school sample examined for this paper, though, show business schools of varying sizes internationalizing. Is that a reflection of current trends post dating the 2001 survey, or an attribute particularly found in the best b-schools sampled?

Two examples suggest the former to be the case - that internationalization is occurring at smaller schools, too, and not only at those ranked nationally as being the elite best. At New York's Iona College (private), for example, the business school core has globalized through infusion and designated courses, an interdisciplinary major available to undergraduates, language and a variety of study abroad options provided and encouraged, and an IB certificate program available at no extra charge to MBA students (Shetty \& Rudell, 2002). Furthermore, a recent study compared Ramapo College of New Jersey (public) to 12 other New Jersey colleges and universities. Although it is not the largest of the 13 schools compared, and only one of two that are not universities, Ramapo College offered the most IB courses and was the only one to require its IB majors to fulfill language, regional studies, and international fieldwork (Dahan, 2006).

Size may be operative in other ways, then. At both Iona College and Ramapo College, relatively small but internationalized faculty clusters interested in globalizing their schools' business programs seem to have been instrumental in developing comprehensive IB programs.

Whatever their origins, and wherever they are found, what is the reach of internationalized business programs? Data establishing the size of IB majors was among the most difficult to collect, perhaps reflecting the small size and in-progress nature of many IB majors. Very few schools included these figures on their websites and fewer still responded to direct queries. What little data available shows IB major enrollments ranging from 22 to 56 students. The reach of such programs may be further narrowed by their current enrollment patterns. As mentioned above, IB majors are most likely to enroll international students (Shetty \& Rudell, 2002).

What scope should business schools seek when internationalizing their programs? AACSB Assurance of Learning Standard \#15 describes effective business learning as occurring on two tracks: management-specific knowledge and skills, and general knowledge and skills (AACSB International, 2006). Literature identifying the components of effective IB learning parallels this. It reports both the need for technical ability to perform functional responsibilities, and knowledge and skill sets to perform in cross-cultural environments. As important as technical 
ability is to possess, though, it is seldom the cause of expatriate failure (Shen, 2005). Conversely, international expertise, foreign language ability, knowledge related to IB (Yu, CMJ., Guan, JL, Yang, KP. \& Chiao, YC, 2005) cultural self-awareness and consciousness, problem solving, critical thinking, conflict resolution, interpersonal skills, global mindset (Ahlawat, 2006), communication, initiative, business ethics, ability to learn and adapt, and self-control (Yu et. al., 2005) are among IB competencies identified as vital to possess.

The outcomes of internationalized business programs, then, are likely to be greatest when functional knowledge is learned within relevant international frameworks, and combined with development of mind sets and skill sets IB assignments tend to call upon. The reach of internationalized business programs is likely to be broadest through infusion of the core. The reach is likely to be deepest through discrete requirements, programs, and related experiential learning opportunities. In determining the optimal alignment of program components for their mission and students, educators seeking guidance may find Table 6 helpful. It summarizes IB competencies the literature suggests as important to target, the IB standards posted by NBEA, and curriculum standards advanced by AACSB.

Table 6: Core IB Competencies and Curriculum Standards

\begin{tabular}{|c|c|}
\hline Attribute & Characteristics \\
\hline $\begin{array}{l}\text { Core IB Competencies } \\
\text { Technical/functional ability is important but } \\
\text { not sufficient, as it is not usually the cause of } \\
\text { expatriate failure }\end{array}$ & $\begin{array}{l}\text { Ability to learn and adapt } \\
\text { Business ethics } \\
\text { Communication } \\
\text { Conflict resolution } \\
\text { Critical thinking } \\
\text { Cultural self-awareness and consciousness } \\
\text { Foreign language ability } \\
\text { Global mindset } \\
\text { Initiative } \\
\text { International expertise } \\
\text { Interpersonal skills } \\
\text { Knowledge related to IB } \\
\text { Problem solving } \\
\text { Self-control }\end{array}$ \\
\hline $\begin{array}{l}\text { AACSB Standards } \\
\text { Business schools should prepare students for } \\
\text { careers in the global context; curricula should } \\
\text { provide management - specific and general } \\
\text { knowledge and skills }\end{array}$ & $\begin{array}{l}\text { Analytic skill and reasoning } \\
\text { Communication } \\
\text { Creation of value through integrated production and distribution } \\
\text { Ethical and legal responsibilities } \\
\text { Ethical understanding and reasoning } \\
\text { Financial theories, analysis, reporting, and markets } \\
\text { Group and individual dynamics } \\
\text { Multicultural and diversity understanding } \\
\text { Reflective thinking } \\
\text { Use of information technology }\end{array}$ \\
\hline IB is central to business education today & $\begin{array}{l}\text { Awareness of interrelationship of political policy and economic practice } \\
\text { Competence in communication strategies improving IB relations } \\
\text { Grasp on global interplay of culture, politics, law, economics, and ethics } \\
\text { Identification of forms of IB business ownership and opportunities } \\
\text { Knowledge of IB finance, management, marketing, and trade relations }\end{array}$ \\
\hline
\end{tabular}

\section{LIMITATIONS AND RECOMMENDATIONS FOR FUTURE RESEARCH}

The sample used in this study was drawn from five different lists to provide a strong foundation. Conducting primary research was essential to the findings. The natural starting place for that research was the website of each school. Locating the information desired to describe the various attributes of internationalized business school education was more difficult than expected. The websites vary in information they carry, ease with which that information can be located, and frequency of updates. Other research data collection methods including accessing alternate collectors of such data, making direct contact with the schools, and conducting additional 
secondary research helped to fill in any critical gaps for this study. Those experiences, however, also provided insight into the accessibility of information about IB education to prospective students and faculty. As schools seek to extend the reach and impact of their internationalized business programs, creating a readily available and centralized information source presenting program features and requirements would seem to facilitate their efforts

At a recent international academic conference, reach and impact of IB education stimulated discussion among both U.S. business school faculty and administrators experienced in and wrestling with IB education (Society for Advancement of Management International Business Conference, 2007). Consistent with trends identified in the literature, these Conference discussants confirmed the tendency of IB majors in U.S. business schools to be mostly international students and of IB instructors to be largely international faculty. From this, they raised a complex question. If IB majors are primarily international students, where in the curriculum do U.S. business students gain requisite international preparation? Further, can the curriculum be optimally globalized if internationalization is the mindset of a subset of the faculty?

In addition to the routes already described as ways to help internationalize business students other than those majoring in IB (integration, focus, and hands-on), the Conference discussants then collectively pointed to another: the value of internationalizing non-international business school faculty. That suggestion is reinforced by Shetty \& Rudell's documentation of Iona College's having done just that as one factor in the successful internationalization of its business school (2002).

The Conference discussants provided additional examples with which they had direct experience. Hiring criteria for all new faculty members at one discussant's school, for example, requires that the applicant's vita includes research involving global aspects. The discussant reported that inclusion of active international engagement among qualifications for every new faculty hire to have significantly increased the international nature of the school's overall curriculum.

Another Conference discussant explained that he is completing his Ph.D. at a business school outside the U.S., feeling it provides an international focus he found lacking in comparable U.S. programs. He provided a firsthand substantive example supporting Kaufman \& Johnson's (2006) recommendation that U.S. undergraduate education incorporate international foci as do curriculum in many other countries, and specifically suggested European higher education as a model for U.S. business schools to benchmark. Exploring internationalized business curriculum in countries outside the U.S. would seem to be a worthwhile area for future research.

Discussants at the Conference in singular voice expressed that any route a school takes to internationalize curriculum would be furthered by instructors who are internationalized. A silence occurred, however, when these experienced IB educators were asked whether and how changes in geopolitics impact resources and demand for IB programs at U.S. schools. There was also no forthcoming answer as to whether and how such programs reflect and adapt to geopolitical changes. These are also areas in which future research could be informative.

A final area for future reflection that follows from this study is the impact of internationalizing undergraduate business education on post-graduation outcomes. Several worthy research questions arise. Are students whose undergraduate business programs have readied them for a global workplace more likely to pursue internationalized careers than those whose programs have not? Are students so prepared more successful than others in the internationalized workplace? Are students so prepared more likely than others to enter MBA programs with strong international components? Are students so prepared more likely than others to enter doctoral programs leading to IB teaching/research careers? Research providing answers to such questions should be valuable to those designing and delivering undergraduate business programs that internationalize optimally.

\section{CONCLUSION}

How likely is it that contemporary business education will align with the imperative that a global economy and evolving requisite skill sets presents? The study conducted for this paper shows positive developments at business schools, and supportive external conditions. Will these be overcome, though, by a coincidental and 
legitimate need for undergraduate business education to continually improve learning outcomes outside IB perimeters? Interestingly, the recent study of Human Resource professionals by The Conference Board (2006; summarized in Appendix 2) conducted jointly with Corporate Voices for Working Families, Partnership for 21st Century Skills, and SHRM suggests there is alignment here too. Many of the skills that the Human Resource professionals report as most important for four year college graduates to possess are among those the literature report as most important for those engaged in international business to possess. Educators seeking to internationalize their programs by incorporating attributes identified in this paper are likely, as a result, to be enhancing their preparation of all of their students for today's increasingly global workplace.

Results from this study suggest that best b-schools are internationalizing curriculum, and provide examples from which schools of varying characteristics can draw. There also appears to be room for innovation and individuality in crafting business programs that align core competencies with academic standards. In fact, the best $b$ school sample points to a fifth route to internationalization of business school curriculum. In addition to internationalizing through focus, hands-on, integration, and specialization, relevant campus activity also seems to have a positive impact. Engagement in IB through student organizations and research in CIBER or other IB centers on campus appears to be prevalent at best b-schools. In conclusion, Table 7 summarizes the alignment between routes to internationalization of curriculum and best practices found.

Table 7: IB Curricular Routes and Best Practices Found

\begin{tabular}{|l|l|}
\hline \multicolumn{1}{|c|}{ Curricular Route } & \multicolumn{1}{c|}{ Best Practices Found } \\
\hline Focus & IB courses in functional areas, language, and/or regional studies \\
\hline Hands-on & IB experiential learning through internship, partnership, simulation, and/or study abroad \\
\hline Integration & IB infused throughout core courses \\
\hline Other campus activity & IB student organizations, and IB research in CIBER or other centers \\
\hline Specialization & IB major/concentration \\
\hline
\end{tabular}

\section{REFERENCES}

1. AACSB International - The Association to Advance Collegiate Schools of Business. AACSB International Accreditation. February 9, 2007, from http://www.aacsb.edu/general/instlists.asp?lid=2.

2. AACSB International - The Association to Advance Collegiate Schools of Business. (2006, January 1). Eligibility Procedures and Accreditation Standards for Business Accreditation, 9.

3. Ahlawat, S. (2006, March). Competing in the global knowledge economy: Implications for business

4. $\quad$ education. Journal of American Academy of Business, 8 (1), 101 (5).

5. America's best graduate schools: A look at what's new on campus, from law school to the M.B.A., plus our signature rankings. (2006, April 10). U.S. News \& World Report, 60-61.

6. $\quad$ Best business programs. (2006, August 28). U.S. News \& World Report, 122.

7. Best practices: CIBEs meet the current training needs of U.S. businesses. International Education Programs Service. February 6, 2007, from http://www.ed.gov/about/offices/list/ope/iegps/cibetraining.html.

8. Collegiate Employment Research Institute (Michigan State University). Executive summary. Recruiting Trends, 2006-2007. February 18, 2007, from http://www.ceri.msu.edu.

9. Cornell University. Cornell University Undergraduate Business Program. February 9, 2007, from http://business.aem.cornell.edu.

10. Dahan, N. (2006, June 2). Report to the Provost on the international business program. Ramapo College of New Jersey, 1-11.

11. Emory University. Goizueta Business School. February 9, 2007, from http://www.goizueta.edu.

12. Farrell, D. (2006, March 22). Don't be afraid of offshoring. Business Week online. February 17, 2007, from http://www.Business Week.com.

13. Fifteen years in the making of CIBEs: Towards a globally competent U.S. workforce. International Education Programs Service. February 6, 2007, from http://www.ed.gov/about/offices/list/ope/iegps/cibe history.html. 
14. Florida International University. Florida International University - College of Business Administration. February 9, 2007, from http://cba.fiu.edu.

15. Fugatte, D. \& Jefferson, R. (2001, January/February). Preparing for globalization - Do we need structural Change for our academic programs? Journal of Education for Business, 76 (3), 160- (7).

16. Gangemi, J. (2006, March 21). The jobs come looking for grads. Business Week online. February 17, 2006, from http://www.Business Week.com.

17. Georgetown University. McDonough School of Business - Georgetown University. February 9, 2007, from http://www.msb.edu.

18. Harvard University. Harvard Business School. February 16, 2007, from http:// www.hbs.edu.

19. Johnson, J., Lenartowicz, T. \& Apud, S. (2006, July 1). Cross-cultural competence in international business: Definition and a model. Journal of International Business Studies. February 6, 2007, from http://www.accessmylibrary.com/coms2/summary 0286 16315658 ITM.

20. Kaufman, H. \& Johnson, T. (2006, July/August). Basic training for the global marketplace. Chief Executive, 219, 26.

21. Lavelle, L. \& Lehman, P. (2006, October 23). The best b-schools of 2006. Business Week, 54-63.

22. Lavelle, L., Gerdes, L., Jespersen, F. \& Gloeckler, G. (2006, May 8). The best undergraduate business schools. Business Week, 76-94.

23. Massachusetts Institute of Technology. MIT Sloan School of Management. February 10, 2007, from http://mitsloan.edu.

24. McCaughey, D. \& Bruning, N. (2005). Enhancing opportunities for expatriate job satisfaction: HR strategies for foreign assignment success. HR. Human Resource Planning, 28 (4), 21 (9).

25. Michigan State University. CiberWeb - Centers for International Business Education and Research. February 10, 2007, from http://ciberweb.msu.edu.

26. New York University. NYU Stern. February 10, 2007, from http://www.stern.nyu.edu.

27. NBEA. National Business Education Standards, Achievement Standards, International Business. February

28. 16, 2007, from http://www.nbea.org/culliculum/s_intbus.html.

29. Northwestern University. (2006, December 1). Undergraduate Programs. February 16, 2007, from http://www.northwestern.edu/academics/undergraduate.

30. San Diego University. (2006, February 12). College of Business Administration. February 13, 2007, from http://www.sdsu.edu/business.

31. Sengupta, S. (2006, October 17). In a twist, Americans appear in ranks of Indian firms. The New York Times.November 17, 2006, from http://select.nytimes.com.

32. Sengupta, S. (2006, October 17). Skills gap threatens technology boom in India. The New York Times. November 17, 2006, from http://select.nytimes.com.

33. Shen, J. (2005). International training and management development theory: Theory and reality. The Journal of Management Development, 24 (7/8), 656 (11).

34. Shetty, A. \& Rudell, F. (2002, November/December). Internationalizing the business program - A perspective of a small school. Journal of Education for Business, 78 (2), 103.

35. Society for the Advancement of Management International Business Conference: Global Challenges and Governance. (2007, March 25 - 28). Las Vegas, Nevada.

36. Stanford University. Academic Programs. February 16, 2007, from http:// www.stanford.edu/home/academics.

37. Temple University. (2007, February 9). The Fox School of Business - Temple University. February 11, 2007, from http://www.fox.temple.edu.

38. The Conference Board. (2006, October 2). Most young people entering the U.S. workforce lack critical Skills essential for success. March 1, 2007, from http://www.conference-board.org.

39. They love It here, and here, and here. (2006, June 4). Business Week online. February 17, 2007, from http://www.Business Week.com.

40. University of California. University of California - Berkeley Haas School of Business. February 9, 2007, From http://www.haas.berkeley.edu.

41. University of Chicago. The University of Chicago - The College. February 16, 2007, from http://www.college.uchicago.edu. 
42. University of Michigan. Michigan Ross School of Business. February 10, 2007, from

http://www.bus.umich.edu.

43. University of Missouri. College of Business Administration at the University of Missouri - St. Louis.

February 10, 2007, from http://www.umsl.edu/divisions/business.

44. University of North Carolina. UNC Kenan-Flagler Business School. February 10, 2007, from

http://www.kenan-flagler.unc.edu.

45. University of Pennsylvania. Wharton-University of Pennsylvania. February 10, 2007, from http://www.wharton.upenn.edu.

46. University of South Carolina. Moore School of Business - University of South Carolina. February 11, 2007, from http://mooreschool.sc.edu.

47. University of Texas. (2007, February 2). McCombs School of Business. February 11, 2007, from http://www.mccombs.utexas.edu.

48. University of Virginia. McIntire School of Commerce. February 11, 2007, from http: //www.commerce. virginia.edu.

49. Walton, J. \& Basciano P. (2006, September). The internationalization of American business education: Are U.S. business students less ethnocentric? The Business Review, 5 (1), 282 (5).

50. Washington University. Olin School of Business. February 11, 2007, from http://www.olin.wustl.edu.

51. Where the jobs are: Everywhere. (2007, January 22). Business Week online. February 17, 2007, from http://www.businesssweek.com.

52. Yu, CMJ., Guan, JL, Yang, KP. \& Chiao, YC. (2005, October 12). Developing the skills for international business management - the implications of the management education opportunity grid. Journal of

Teaching in International Business, 16 (4), 5.

\section{ENDNOTES}

1 The Business Week listings states the rankings are based on the following institutional measures of excellence: a) the undergraduate business program (see endnote \#2, below), b) AACSB accreditation, and c) strong performance in at least two of the following - SAT and ACT scores, percentage of applicants accepted, and percentage of students from the top tenth of their high school graduating class.

2 The Business Week listings identifies five sources of data used: student survey, recruiter survey, median start salary for graduates, number of graduates accepted into the top 35 U.S. MBA programs, and academic quality (SAT/ACT scores for business majors, full-time ratio of faculty to staff in the business school, average class size of business classes, percentage of business majors in internships, and number of hours students spend preparing for classes).

${ }^{3}$ The authors have made every attempt to accurately report on each school's program and requirements. It is possible that there may have been changes since the data was collected, or as it was posted, in February, 2007.

${ }^{4}$ Academic literature particularly foundational in identifying attributes for this study's primary research include

Ahlawat, S., 2006; Dahan, N., 2006; Fugatte, D. \& Jefferson, R., 2001; Johnson, J., Lenartowicz, T. \& Apud, S., 2006; McCaughey, D. \& Bruning, N., 2005; NBEA, 2007; Shen, J., 2005; Shetty, A. \& Rudell, F., 2002; Yu, CMJ., 2005; and Walton, J. \& Basciano P., 2006.

${ }^{5}$ Some schools offer IB programs as majors, while others offer IB programs as concentrations. As those labeled as majors do not significantly differ from those labeled as concentrations, both are referred to in this paper as "majors." Only one of the schools, the University of Missouri-St. Louis, offered a minor in International Business. Its minor requires students to complete any five courses in International Business.

${ }^{6}$ Emory, Georgetown, New York University, University of Virginia, University of South Carolina - Columbia, and Washington - St. Louis.

${ }^{7}$ Cornell, Massachusetts Institute of Technology, and University of Michigan.

${ }^{8}$ Emory, New York University, University of Pennsylvania, and University of South Carolina.

9 Florida International, New York University, San Diego State, Temple, University of California - Berkeley, University of Michigan - Ann Arbor, University of Missouri - St. Louis, University of North Carolina - Chapel Hill, University of Pennsylvania, University of South Carolina - Columbia, and University of Texas - Austin.

${ }^{10}$ University of Michigan - Ann Arbor does not.

${ }^{11}$ University of South Carolina - Columbia.

${ }^{12}$ San Diego State and University of Texas - Austin. 
${ }^{13}$ San Diego State, Temple, and University of Texas - Austin; a fourth school, Florida International, requires an internship of its honors students.

${ }^{14}$ San Diego State, University of California - Berkeley, University of Pennsylvania, University of South Carolina - Columbia, and University of Texas - Austin.

${ }^{15}$ University of California - Berkeley.

${ }^{17}$ Emory, New York University, University of Pennsylvania, and University of South Carolina - Columbia.

${ }^{18}$ Florida International, San Diego State, University of Missouri Honors, and University of Virginia

${ }^{19}$ Temple.

${ }^{20}$ Finance, International Business, Management, Marketing, Strategy, and two electives.

\section{Appendix 1}

Attributes Used for Data Collection

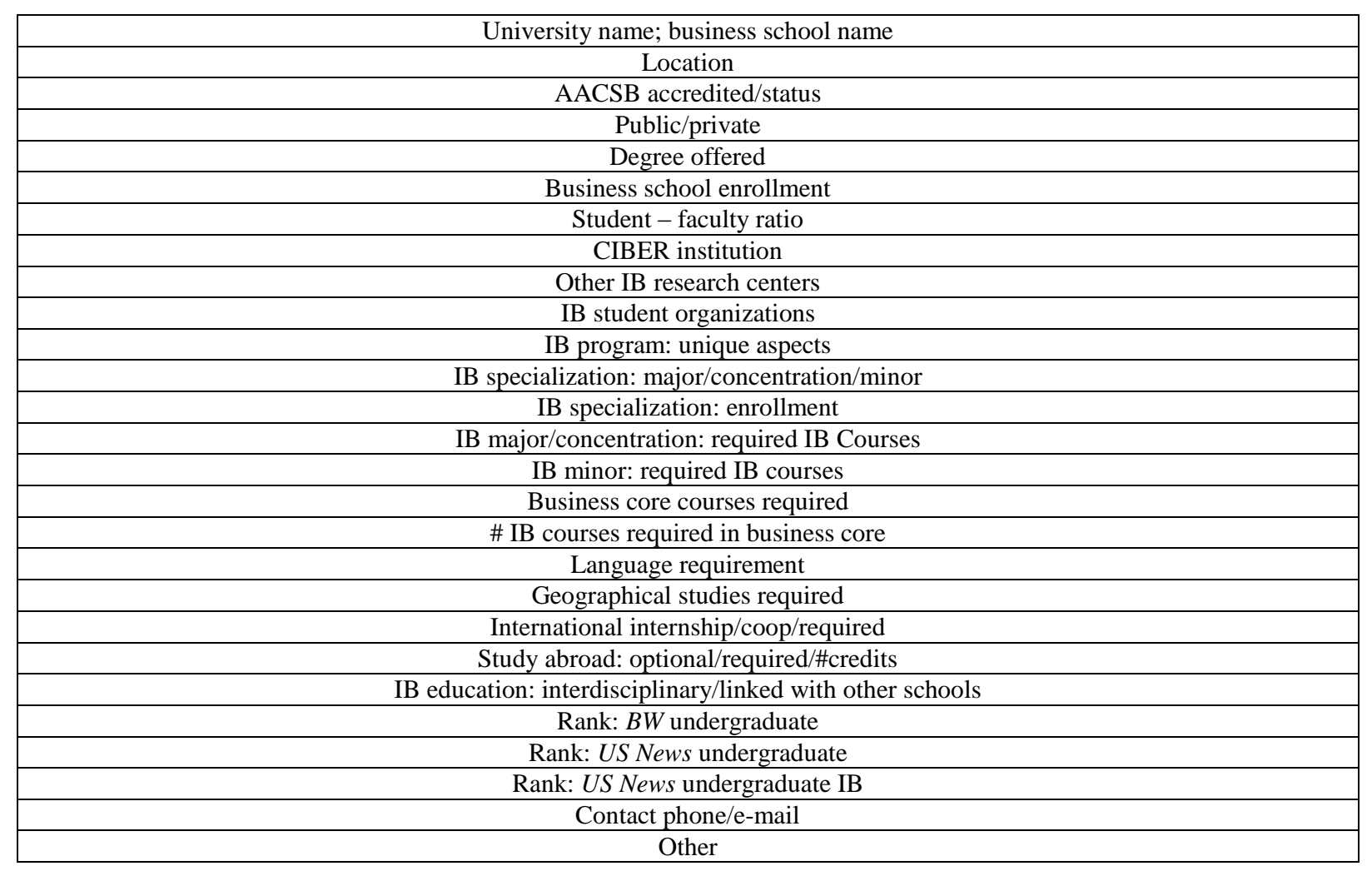


Appendix 2

Very Important Skill Sets for 4-Year College Graduates to Possess

\begin{tabular}{|c|c|c|c|}
\hline Attribute & $\begin{array}{c}\text { \% Report } \\
\text { Very Important To Have }\end{array}$ & $\begin{array}{c}\text { \% Report } \\
\text { 4-Year Grads' Excellence; } \\
\text { Ranked }\end{array}$ & $\begin{array}{c}\text { \% Report } \\
\text { 4-Year Grads' Deficiency; } \\
\text { Ranked }\end{array}$ \\
\hline Oral communication & $95.4 \%$ & $24.8 \% ; 7$ & $0.0 \%$ \\
\hline Teamwork/collaboration & $94.4 \%$ & $24.6 \% ; 8$ & $0.0 \%$ \\
\hline Professionalism/work ethic & $93.8 \%$ & $0.0 \%$ & $0.0 \%$ \\
\hline Written communication & $93.1 \%$ & $0.0 \%$ & $27.8 \% ; 1$ \\
\hline $\begin{array}{c}\text { Critical thinking/problem } \\
\text { solving }\end{array}$ & $92.1 \%$ & $27.6 \% ; 3$ & $0.0 \%$ \\
\hline Writing in English & $89.7 \%$ & $0.0 \%$ & $26.2 \% ; 2$ \\
\hline English language & $88.0 \%$ & $26.2 \% ; 4$ & $0.0 \%$ \\
\hline Reading comprehension & $87.0 \%$ & $25.9 \% ; 6$ & $0.0 \%$ \\
\hline Ethics/social responsibility & $85.6 \%$ & $0.0 \%$ & $0.0 \%$ \\
\hline Leadership & $81.8 \%$ & $0.0 \%$ & $23.8 \% ; 3$ \\
\hline Information technology & $81.0 \%$ & $46.3 \% ; 1$ & $0.0 \%$ \\
\hline Creativity/innovation & $81.0 \%$ & $21.5 \% ; 9$ & $0.0 \%$ \\
\hline Lifelong learning/self & $78.3 \%$ & $25.9 \% ; 5$ & $0.0 \%$ \\
\hline direction & $71.8 \%$ & & $0.0 \%$ \\
\hline Diversity & $64.2 \%$ & $28.3 \% ; 2$ & $0.0 \%$ \\
\hline Math & $2006 \%$ & $0.0 \%$ & \\
\hline
\end{tabular}

Note: Data is from The Conference Board, 2006. 


\section{Appendix 3}

Curriculum Detail for Schools with IB Programs

(Data suggest that difference between whether these IB programs are majors or concentrations is largely semantic; "*” indicates a major in a functional business area is required in addition to the IB Program)

\begin{tabular}{|c|c|c|c|}
\hline School & $\begin{array}{c}\text { Ib Courses/Required } \\
\text { (All Are International) }\end{array}$ & $\begin{array}{l}\text { Require Area/ Abroad } \\
\text { Study }\end{array}$ & Require Language \\
\hline U. Pennsylvania * & Require 3 of 24 & $\begin{array}{l}3 \text { global context, + study } \\
\text { abroad }\end{array}$ & 1 upper level \\
\hline $\begin{array}{l}\text { U. Pennsylvania - } \\
\text { Honors } *\end{array}$ & $\begin{array}{l}\text { Require } 3 \text { of } 24 \text {, and senior thesis; joint } \\
\text { degree program with liberal arts }\end{array}$ & $\begin{array}{c}4 \text { international studies, } 4 \\
\text { areas studies, + study } \\
\text { abroad in language } \\
\text { locale }\end{array}$ & 4 upper level \\
\hline U. Virginia & $\begin{array}{c}\text { 4: require } 2 \text { Marketing, }+2 \text { elected } \\
(1 \text { elected is Finance })\end{array}$ & 2 area studies & School-wide \\
\hline Emory * & $\begin{array}{c}\text { Select } 3 \text { (e.g. Management, Finance, } \\
\text { Communication) }\end{array}$ & No & No \\
\hline NYU * & $\begin{array}{l}\text { 4: require Management, }+ \text { Finance or } \\
\text { Marketing, }+2 \text { elected }\end{array}$ & Study Abroad & Recommended \\
\hline U. Texas - Austin & 4: require Trade, Operations, +2 elected & $\begin{array}{l}3 \text { in } 1 \text { region, + study } \\
\text { abroad, }+ \text { intern }\end{array}$ & 2 \\
\hline $\begin{array}{l}\text { U. N. Carolina - } \\
\text { Chapel Hill }\end{array}$ & $\begin{array}{c}\text { Select } 2 \text { of } 7 ; 1 \text { can be a non-IB } \\
\text { international }\end{array}$ & Study abroad & Yes \\
\hline $\begin{array}{l}\text { U. California - } \\
\text { Berkeley }\end{array}$ & 4: require Intro to IB, +3 elected & $3,+$ study abroad & Yes \\
\hline Georgetown & $\begin{array}{l}\text { 4: require Advanced Seminar, }+3 \text { elected } \\
\text { (3/6 are quantitative) }\end{array}$ & $\begin{array}{c}1,+ \text { international } \\
\text { qualification via life/ } \\
\text { work/study abroad/ } \\
\text { Language }\end{array}$ & $\begin{array}{c}\text { Can satisfy international } \\
\text { qualification }\end{array}$ \\
\hline $\begin{array}{l}\text { Washington - } \\
\text { St. Louis }\end{array}$ & $\begin{array}{c}\text { 3: require Global Economy. }+2 \text { elected } \\
\text { (3/8 are quantitative) }\end{array}$ & $\begin{array}{c}2 \text { (can be regional or } 2 \\
\text { other IB courses) }\end{array}$ & No \\
\hline $\begin{array}{l}\text { U. S. Carolina - } \\
\text { Columbia * }\end{array}$ & $\begin{array}{l}\text { 4: require Globalization/Business, }+1 \\
\text { elected each from function, area, and theme } \\
\text { (foreign market entry/growth, } \\
\text { export/import, or cross-cultural } \\
\text { behavior/negotiation) }\end{array}$ & $1,+$ study abroad & 4 courses in 1 language \\
\hline Florida International & $\begin{array}{l}\text { 7: require IB, Management, Finance, } \\
\text { Marketing, Strategy, }+2 \text { elected }\end{array}$ & No & No \\
\hline $\begin{array}{l}\text { Florida International - } \\
\text { Honors }\end{array}$ & $\begin{array}{l}2 \text { honors tracks with different foci: a) } \\
\text { regional area/language, and } \\
\text { b) functional business area }\end{array}$ & $\begin{array}{c}\text { Intern + a) Yes; b) No; } \\
\text { IB community service } \\
\text { project }\end{array}$ & $\begin{array}{l}\text { a) Yes } \\
\text { b) No }\end{array}$ \\
\hline $\begin{array}{l}\text { U. Missouri - St. } \\
\text { Louis }\end{array}$ & $\begin{array}{l}\text { Select } 4 \text { of } 12(3 / 12 \text { are quantitative; } \\
\text { internship is } 1 \text { of the } 12) \text {; has IB minor }\end{array}$ & No & $\begin{array}{l}\text { Yes: International } \\
\text { commerce language }\end{array}$ \\
\hline $\begin{array}{l}\text { U. Missouri - St. } \\
\text { Louis - Honors }\end{array}$ & $\begin{array}{l}\text { 4: require Management, Finance, } \\
\text { Marketing, Strategy }\end{array}$ & Foreign intern & $\begin{array}{c}\text { Yes: International } \\
\text { commerce language }\end{array}$ \\
\hline Temple & $\begin{array}{c}\text { 4: require Trade, Practicum (consult), } 1 \\
\text { quantitative, }+1 \text { other elected }\end{array}$ & Intern & $\begin{array}{l}4 \text { or Latin American } \\
\text { Studies semester }\end{array}$ \\
\hline San Diego State & $\begin{array}{l}\text { 5: require Finance, Marketing, Strategy, }+2 \\
\text { elected in } 1 \text { function (Management, } \\
\text { Finance, Marketing) }\end{array}$ & $\begin{array}{l}2 \text { in } 1 \text { region, + study } \\
\text { abroad or intern }\end{array}$ & $\begin{array}{l}\text { Yes; } 3^{\text {rd }} \text { language for } \\
\text { honors }\end{array}$ \\
\hline $\begin{array}{l}\text { San Diego State - } \\
\text { Honors }\end{array}$ & Honors thesis + senior honors thesis & $\begin{array}{l}2 \text { in } 1 \text { region, }+2 \text { study } \\
\text { abroad semesters, }+ \\
\text { foreign intern }\end{array}$ & $3^{\text {rd }}$ language proficiency \\
\hline
\end{tabular}

Note: Data is current as on AACSB and school websites or in response to query of schools as of 2.28.07 